\title{
MANAJEMEN PEMASARAN PERGURUAN TINGGI SEBAGAI SALAH SATU KUNCI KEBERHASILAN DALAM MENGHADAPI PERSAINGAN
}

\author{
Maryadi*)
}

\begin{abstract}
Nowdays the terms of effective and efficient are more often used in relation to tight competition pattens. Such as a competition also accurs in the education world. Collage are demanded to improve management system, teaching and learning process in order to be able to sustain, develop, and compete. As a non profit institution, collage are expected to make some breakthroughs and innovations to satisfy their consumers. The writer discusses some ideas how to improve school management to maximize the attainment of its educational objectives.
\end{abstract}

Keywords : College Management, Marketing Management, Management Strategy, Segment, Market Goals and research into market.

Pendahuluan

Dalam kondisi krisis multidimensi yang berkepanjangan, pendidikan telah menarik perhatian berbagai pihak setelah bergeser menjadi salah satu pos pengeluaran yang semakin besar dan memberatkan di sebahagian besar anggota masyarakat. Tingginya biaya pendidikan merupakan konsekuensi dari meningkatnya biaya ditambah lagi dengan berkurangnya kemampuan para penyandang dana pendidikan.

Pendidikan yang mahal akan semakin menjadi relativ ketika kita melihat dari sudut pandang yang berbeda. Apabila pendidikan dianggap sebagai suatu bentuk investasi yang akan memberikan suatu benefit di masa mendatang, maka tidak akan terjadi penempatan biaya pendidikan dalam skala prioritas terakhir atau berada dibawah pengeluaran yang konsumtif. Persfektif inilah yang harus diupayakan menjadi sepadan agar tidak terjadi gap pendekatan bagi solusi masalah-masalah seputar pendidikan. Komunikasi yang sering sumbang harus disamakan, paling tidak untuk membuka forum diskusi yang lebih terarah bagi semua pihak yang berkepentingan di dunia pendidikan.

Bermunculannya perguruan tinggi baru menimbulkan fenomena dalam dunia pendidikan.bentuk dan pendekatan pendidikan semakin berkembang dan kompleks. Tidak hanya pemain-pemain lama yang mengembangkan perguruan tinggi yang sudah ada namun juga dari pelaku usaha non pendidikan dan bahkan penyelenggara pendidikan dari luar negeri. Secara objektif, masyarakat semakin sulit menentukan pilihan lembaga pendidikan yang akan digunakan.

Sehubungan dengan kurikulum berbasis kompetensi, maka pendekatan satu arah dosen dengan dengan mahasiswa semakin dikurangi. Metode-metode partisipatif berdasarkan kompetensi akan semakin digunakan. Peserta didik akan semakin mendapat perhatian secara pribadi. Dengan semakin ditambahnya fitur-fitur pengajaran tersebut, maka biaya operasional secara rasional akan bertambah. Hal yang logis ketika kualitas suatu produk/ layanan ditingkatkan maka akan meningkatkan biaya.

Dilain pihak pengelolaan suatu lembaga menuju organisasi yang efektif dan efesien merupakan syarat mutlak keberhasilan organisasi tersebut. Tidak terkecuali lembaga pendidikan yang juga akan semakin dituntut menjadi organisasi yang tepat sasaran dan berdayaguna. Sekolah sebagai lembaga pendidikan formal memerlukan suatu system pengelolaan yang profesional.

Perguruan tinggi sebagai organisasi nirlaba telah banyak mengalami redefinisi dalam hal bagaimana seharusnya perguruan tinggi dapat tetap beroperasi dalam iklim hypercompetitive. Visi dan misi perguruan tinggi dengan pendekatan situasional akan seringkali disalahartikan oleh masyarakat. 
Dari paparan kondisi pendidikan diatas, maka pengelolaan perguruan tinggi memainkan peranan yang penting dan menentukan keberlangsungan serta strategi yang bagaimana diperlukan perlu dibahas lebih lanjut.

\section{Manajemen Perguruan Tinggi}

Sebagai salah satu komponen utama dalam system pendidikan, sekolah sudah selayaknya memberikan kontribusi yang nyata dalam meningkatkan kualitas simber daya manusia (SDM). Hal ini tidak terlepas dari seberapa baik perguruan tinggi itu dikelola. Apabila perguruan tinggi Dianalogikan sebagai mesin produksi, maka kualitas output akan relevan sekali dengan kualitas mesin tersebut.

Pengelolaan pendidikan bermutu tidak terlepas dari fungsi-fungsi manajemen secara umum yaitu: perencanaan (planning), pengorganisasian (Organizing), pengarahan (Directing) dan pengendalian (Controlling). Fungsi-fungsi manajerial tersebut hendaknya dilakukan oleh setiap pengelola perguruan tinggi secara efektif dan efisien, dimana pimpinan secara khusus merupakan orang yang bertanggung jawab dalam pengelolaan sumber daya perguruan tinggi yaitu : SDM, mahasiswa, metode, sarana prasarana dan pasar.

Manajemen perguruan tinggi berbasis kualitas (Quality Education) merupakan dasar efektifitas dari segala keberhasilan program-program perguruan tinggi. Pendidikan yang bermutu merupakan standar kesesuaian tampilan (performance) terhadap atribut-atribut yang dianggap penting oleh para pelanggan/pengguna jasa pendidikan. Atribut-atribut mutu tersebut hendaknya diketahui oleh penyelenggara perguruan tinggi sehingga dalam operasionalisasi kegiatan dapat mengacu pada kepentingan mutu pelanggan.

Kegiatan pendidikan di perguruan tinggi sebagai salah satu bentuk pelayanan jasa (service) memiliki bentuk proses yang sirkuler bukan linier atau sekedar jual beli. Dalam system pendidikan, perguruan hendaknya dapat memberikan inisiatif peran yang dapat memancing peran positif komponen system pendidikan lainnya.

\section{Strategi Pengelolaan Perguruan Tinggi}

Masyarakat mengharapkan perguruan tinggi dapat memberikan penyediaan pelayanan pendidikan secara maksimal. Harapan yang besar pada perguruan tinggi memerlukan energi yang besar. Untuk itu diperlukan banyak dukungan dari berbagai pihak. Dinegara-negara maju, perlakukan khusus kepada lembaga yang menyelenggarakan pendidikan umum sudah sangat kondusif. Tentunya tidak terlepas dari kemampuan pemerintahnya.

Perguruan tinggi dalam menjalankan kegiatan pendidikan sangat tergantung kepada jenis sumber pemasukan keuangan, yaitu: (1) pemilik organisasi,(2) masyarakat pengguna dan (3) pihak ketiga. Masalah yang sering timbul adalah bagaimana jaminan ketersediaan dana tersebut secara jelas dan continue, tanpa menganggu kelangsungan kegiatan operasional perguruan tinggi.

Masalah lain yang dapat timbul adalah ketika para peyandang dana memiliki kepentingan yang berbeda adalah sangat penting untuk sekolah mencari sumber-sumber dana yang tidak memiliki kepentingan yang saling berbenturan. Tentunya sangat adil ketika visi dan misi sekolah diawali dari tujuan lembaga pembentukannya (pemerintah atau yayasan).

Dalam kondisi tertentu, perguruan tinggi yang mempunyai keterbatasan sumber daya yang dimiliki, maka strategi allians merupakan bentuk kerjasama dengan lembaga lain yang paling aman dijalankan dibandingkan metode kerja sama lainnya (piggybacking dan merger), ketika identitas organisasi tersebut masih terjaga. Hal ini sangat logis ketika kompetensi dan kolaborasi antar lembaga pendidikan akan menjadi semakin dinamis, maka untuk materi-materi tertentu, perguruan tinggi dapat bekerjasama dengan mitra kompeten. Sebagai contoh untuk penyediaan pendidikan keterampilan computer bias menggandeng lembaga pendidikan computer 
yang sudah ada. Namun perlu diperhatikan bahwa strategi ini memiliki konsekuensi terpengaruhnya imej perguruan tinggi oleh lembaga mitra. Untuk itu diperlukan penetapan mitra. yang memiliki visi dan misi yang sejalan serta reputasi yang baik.

Pola persaingan antar perguruan tinggi dapat disikapi sebagai suatu iklim yang kondusif dalam pertumbuhan penyelenggaraan pendidikan. Isu-isu komersialisasi pendidikan merupakan konsekuensi logis dari tidak meratanya pasar yang terlayani oleh perguruan tinggi yang ada. Timbulnya perguruan tinggi favorit adalah akibat atribut-atribut perguruan tinggi yang secara panca indra tertangkap sebagai perguruan tinggi yang dapat memenuhi kebutuhan pasar. Atribut-atribut perguruan tinggi antara lain visi dan misi, sarana prasarana fisik, reputasi pendidik, prestasi mahasiswa dan lulusan yang dihasilkan perguruan tinggi.

Dilain pihak perlu pengelompokan pasar pengguna jasa pendidikan yang luas ke dalam beberapa segmen. Perguruan tinggi pasar pengguna jasa pendidikan yang luas ke dalam beberapa segmen. Sekolah dapat lebih menajamkan strategi pengelolaan sehubungan dengan pasar yang menjadi segmennya. Akan lebih baik perguruan tinggi menjadi yang terbaik dikelasnya.

\section{Manajemen Pemasaran Perguruan Tinggi}

Kotler mendefinisikan pemasaran sebagai suatu proses dan manajerial dimana individu dan kelompok mendapatkan kebutuhan dan keinginan mereka dengan menciptakan, menawarkan dan bertukar sesuatu yang bernilai satu sama lain. Dengan demikian pemasaran produk dan jasa, termasuk perguruan tinggi yang terkait dengan konsep : permintaan, produk, nilai dan kepuasan pelanggan.

Konsep produk dalam dunia pendidikan sendiri terbagi atas jasa : kurikuler, penelitian, pengembangan kehidupan bermasyarakat, ekstrakurikuler dan administrasi. Bentuk produk-produk tersebut hendaknya sejalan dengan permintaan pasar atau keinginan pasar yang diikuti oleh kemampuan dan kesediaan dalam membeli jasa pendidikan.

Perguruan tinggi hendaknya dapat berorientasi pada kepuasan pelanggan. Selain itu juga perlu mencermati pergeseran konsep keuntungan pelanggan menuju nilai dari jasa yang terhantar. Perguruan tinggi mahal tidak menjadi masalah sepanjang manfaat yang dirasakan mahasiswa melebihi biaya yang dikeluarkan. Dan sebaliknya perguruan tinggi murah bukan jaminan akan diserbu calon siswa apabila dirasa nilainya rendah.

Langkah-langkah kegiatan dalam mengelola pemasaran perguruan tinggi yaitu :

\section{Identifikasi Pasar}

Tahapan pertama dalam pemasaran Perguruan Tinggi adalah mengidentifikasi dan menganalisis pasar untuk mengetahui kondisi dan ekspektasi pasar termasuk atribut-atribut pendidikan yang menjadi kepentingan konsumen pendidikan. Termasuk dalam tahapan ini adalah pemetaan dari sekolah lain.

2. Segmentasi pasar dan Positioning

Penentuan target pasar merupakan langkah selanjutnya dalam pengelolaan masalah pemasaran perguruan tinggi. Dalam pasar yang sangat beragam karakternya, perlu ditentukan atributatribut apa yang menjadi kepentingan utama bagi pengguna pendidikan. Secara umum pasar dapat dipilih berdasarkan karakteristik demografi, geografi, psikografi maupun perilaku. Dengan demikian perguruan tinggi akan lebih mudah menentukan strategi pemasaran sehubungan dengan karakteristik dan kebutuhan pasar.

Setelah kita mengetahui karakter pasar, maka kita akan menentukan bagian pasar mana yang akan kita layani. Tentunya secara ekonomis, melayani pasar yang besar akan membawa perguruan tinggi masuk kedalam skala operasi yang baik. 
3. Diferensiasi Produk

Melakukan diferensiasi merupakan cara yang efektif dalam mencari perhatian pasar. Dari banyaknya perguruan tinggi yang ada, orang tua mahasiswa akan kesulitan untuk memilih perguruan tinggi anaknya dikarenakan atribut-atribut kepentingan antar perguruan tinggi semakin standar. Perguruan tinggi hendaknya dapat memberikan tekanan yang berbeda dari perguruan tinggi lainnya dalam bentuk kemasan yang menarik seperti logo dan slogan. Fasilitas internet mungkin akan menjadi standar, namun jaminan internet yang aman dan bersih akan menarik perhatian orang tua.

Melakukan perbedaan secara mudah dapat pula dilakukan bentukbentuk tampilan pisik yang tertangkap panca indra yang memberikan kesan baik, seperti pemakaian seragam yang menarik, kampus yang bersih atau stiker perguruan tinggi.

4. Komunikasi Pemasaran

Akhirnya pengelola perguruan tinggi hendaknya dapat mengkomukasikan pesan-pesan pemasaran perguruan tinggi yang diharapkan pasar. Perguruan tinggi sebagai lembaga ilmiah akan lebih elegan apabila bentuk-bentuk komunikasi disajikan dalam bentuk/ format ilmiah, seperti menyelenggarakan kompetisi bidang studi, forum ilmiah/seminar dan yang paling efektif adalah pulikasi prestasi oleh media independent seperti berita dalam media massa.

Komunikasi yang sengaja dilakukan sekolah dalam bentuk prpmosi atau bahkan iklan sekalipun perlu menjadi pertimbangan. Bentuk dan materi pesan agar dapat dikemas secara elegan namun menarik perhatian agar perguruan tinggi tetap dalam imej perguruan tinggi sebagai pembentuk karakter dan nilai yang baik.

Publikasi yang sering terlupakan namun memiliki pengaruh yang kuat adalah promosi. Alumni yang sukses dapat membagi pengalaman atau bukti keberhasilan perguruan tinggi.

Dengan langkah-langkah kegiatan tersebut diatas maka perguruan tinggi dapat mencapai keseimbangan dalam operasionalisasi pengajaran dalam kondisi memperebutkan 'kue' dari banyak penyelenggara perguruan tinggi. Dengan demikian masalah perguruan tinggi kekurangan mahasiswa tidak terjadi lagi.

Organisasi pendidikan hendaknya memiliki system pengelolaan manajemen yang dapat memaksimalkan atribut-atribut yang dianggap pasar sebagai atribut yang penting dalam sebuah institusi pendidikan. Sehingga konsep pemasaran pendidikan yang berwawasan jasa/produk pelayanan akan berkembang menjadi konsep pemasaran pendidikan yang berorientasi pasar bahkan berwawasan masyarakat (society).

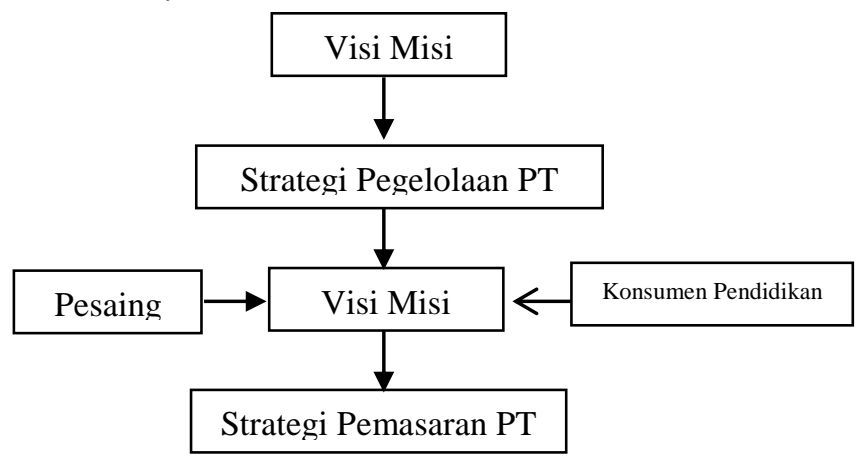

Konsep Pemikiran Pengelolaan Pemasaran PT

Langkah strategi selanjutnya adalah bagaimana pelayanan perguruan tinggi dapat terlihat sebagai apa yang diharapkan konsumen. Kesenjangan yang sering terjadi adalah adanya perbedaan persepsi kualitas maupun atribut jasa pendidikan. Berdasarkan hasil penelitian terhadap organisasi jasa, termasuk perguruan tinggi, didapati beberapa cirri-ciri organisasi jasa yang baik yaitu memiliki (Kotler, 2000):

1. Konsep strategis yang memiliki focus kepada konsumen

2. Komitmen kualitas dari manajemen puncak

3. Penetapan standar yang tinggi 
4. Sistem untuk memonitor kinerja jasa

5. Sistem untuk memuaskan keluhan pelanggan

6. Memuaskan karyawan sama dengan pelanggan

Untuk mencapai cirri-ciri tersebut diatas, kita sepatutnya mengetahui parameter-parameter apa saja yang akan menjadi kekuatan dalam organisasi jasa. Setidaknya ada lima determinan kualitas jasa (Parasuraman, 1985) yaitu : keadaan responsive, keyakinan, empati dan wujud.

Keandalan merupakan kemampuan untuk melaksanakan jasa yang dijanjikan dengan tepat dan terpercaya. Dalam setiap realisasi pelayanan sekolah hendaknya sesuai dengan apa yang telah dijanjikan. Dan selanjutnya bagaimana dengan kondisi pelayanan yang ada dapat membantu keberhasilan proses belajar mengajar.

Responsif merupakan kemampuan untuk membantu pelanggan dan memberikan jasa dengan cepat. Kecepatan waktu juga harus diikuti oleh ketepatan waktu sehingga kualitas pelayanan tidak dikorbankan. Penanggung jawab kegiatan dalam hal hal ini pengelola perguruan tinggi yang merupakan ujung tombak dalam merespon stake holder. Mereka hendaknya dapat menjawab setiap pertanyaan yang paling tidak dapat menjadi pendengar yang baik ketika keluhan muncul.

Keyakinan merupakan pengetahuan dan kompetensi dosen dan kemampuan mereka untuk menimbulkan kepercayaan dan keyakinan. Keyakinan pasar yang timbul merupakan suatu reputasi perguruan tinggi yang dibangun dalam kurun waktu tertentu dan yang utama merupakan cerminan dari kualitas dosen. Untuk itu diperlukan strategi pendekatan pemasaran internal yaitu bagaimana pemilik perguruan tinggi dapat memberikan peningkatan kemampuan/kompetensi dosen serta memotivasi dosen agar dapat semakin yakin akan organisasinya.

Empati merupakan syarat untuk peduli, memberi perhatian pribadi bagi pelanggan. Pada prinsipnya setiap manusia senang apabila diperhatikan orang lain. Hal ini dapat menjadi dasar perlakuan perguruan tinggi untuk memperhatikan setiap perkembangan mahasiswanya. Pengelolaan administrasi, termasuk basisdata, yang baik dapat memudahkan pendekatan ini.

Berujud merupakan penampilan fasilitas fisik, peralatan, personil dan media komunikasi. Umumnya jasa pendidikan akan semakin terlihat baik ketika fasilitas fisik tersedia secara lengkap dan baik. Untuk menambahkan kewujudan dari jasa pelayanan dapat dilakukan dengan mewujudkan yang tidak berwujud. Imej perguruan tinggi dapat ditimbulkan dengan menempatkan symbol-simbol yang sifatnya menterjemahkan konsep ke dalam tangkapan panca indra.

Dengan melakukan unsur-unsur kualitas pelayanan jasa, maka perguruan tinggi dalam memberikan pelayanan pendidikan adan menjadi unggul dan pada akhirnya akan memudahkan pemasar untuk mengkomunikasikan kekuatan yang dimiliki perguruan tinggi. Sehingga dalam mengantarkan pesan visi dan misi sekolah, masyarakat dapat menangkat lebih sepat, mudah dan paham. Tidak akan terjadi gap cara pandang dan komunikasi karena fakta lebih berbicara keras dari sekedar kata-kata.

Ketika setiap komponen (stakeholder) dalam system pendidikan telah memahami kearah mana perguruan tinggi menuju, maka gap antara permintaan dan penawaran pengguna pendidikan akan semakin kecil. Perguruan tinggi akan lebih menfokuskan pasar sasaran yang sesuai dengan misinya dengan tetap mempertimbangkan kelayakan untuk dapat beroperasi dan merkembang.

\section{Kesimpulan}

Penyelenggara pendidikan dituntut semakin professional dalam mengelola Perguruan Tinggi. Tidak saja menghadapi iklim persaingan yang semakin sengit namun juga tuntutan pasar yang semakin kritis dan rasional. Diperlukan suatu penelitian pasar yang sistematis sehingga perguruan tinggi dapat membuat strategi pemasaran Perguruan Tinggi dengan 
melihat kondisi persaingan lembaga pendidikan dan pasar pendidikan.

Arah pengelolaan pemasaran perguruan tinggi adalah mencapai kepuasan pelanggan. Upaya komunikasi pemasaran akan menekankan pada atribut yang dipentingkan oleh segmen yang dituju. Dengan pengalaman pelanggan yang puas, maka akan dapat menjadi media yang cukup efektif dan obejektif.

Perguruan tinggi berbasis kualitas akan menjadi dasar yang kuat dalam pemasaran produk pendidikan. Determinan kualitas jasa yang perlu dilakukan oleh perguruan tinggi yaitu : keandalan, responsive, keyakinan, empati dan wujud.

Pendidikan yang merupakan proses yang sirkuler akan menempatkan pengelolaan pemasaran perguruan tinggi kepada langkah berkelanjutan yang saling mendukung. Dengan demikian diharapkan perguruan tinggi tidak mengalami kesulitan dalam mendapatkan siswa dengan diketahuinya kondisi pasar pendidikan.

\section{Daftar Pustaka}

Johan, Rita. (2004). Berbagai Masalah Pendidikan di Indonesia, Tabloid
PENABUR Jakarta No. 4 Tahun II Edisi April - Juni 2004.

Kotler, Philip. (2000). Marketing Management, $10^{\text {th }}$ edition. Upper Saddle River: Prentice Hall, Inc.

Parasuraman, A, Valarie A. Zeithhaml, Leonard L. Berry. (1985). Journal of marketing : A conceptual model of service quality and its implication for future research

Tampubolon, Daulat P. (2005). Pendidikan bermutu untuk semua. Makalah Seminar : Meningkatkan Mutu Pendidikan Indonesia, 12 Mei 2005. Jakarta : IBII

Tung, Khoe Yao. (2002) Simponi sedih pendidikan nasional. Jakarta : Abdi Tandur.

*) Penulis adalah Dosen Tetap Yayasan Pendidikan Nobel Indonesia Makassar. 